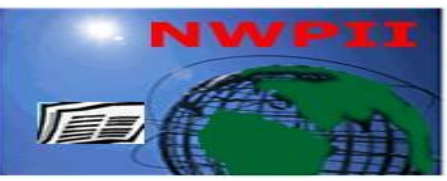

American Journal of Biomedical Sciences

ISSN: 1937-9080

nwpii.com/ajbms

\title{
Relationship between Testosterone Level, Serum Omentin-1 and Insulin Resistance in Obese Men
}

\author{
Samir Ali Abd El-Kaream ${ }^{1 *}$, Samia Abd El-Monem ${ }^{1}$, Magda Mohassab ${ }^{2}$, \\ Gehan Ibrahim Khalil ${ }^{3}$
}

\author{
${ }^{1}$ Applied Medical Chemistry Department, Medical Research Institute, Alexandria University, Alexandria, Egypt \\ ${ }^{2}$ Human Physiology Department, Medical Research Institute, Alexandria University, Alexandria, Egypt \\ ${ }^{3}$ Chemical Pathology Department, Medical Research Institute, Alexandria University, Alexandria, Egypt \\ *Corresponding Author \\ Samir Ali Abd El-Kaream \\ Applied Medical Chemistry Department \\ Medical Research Institute \\ Alexandria University \\ Alexandria 2(03),, Egypt \\ E-mail: samir_ali852006@yahoo.com
}

Received: 14 May 2015; | Revised: 26 May 2015; | Accepted: 15 July 2015

\begin{abstract}
Background: Adipose tissue besides its role in energy storage produces several hormones and cytokines termed adipokines that have widespread effects on carbohydrate and lipid metabolism. Omentin-1 is a newly identified adipokine that increases insulin sensitivity and is highly and selectively expressed in visceral adipose tissue relative to subcutaneous adipose tissue. Objective: The aim of the present work was to evaluate the level of serum omentin-1 and its association with serum testosterone and insulin resistance in obese men. Subjects and Methods: The present study included 20 apparently healthy men their mean BMI was $(21.51 \pm 2.26) \mathrm{kg} / \mathrm{m} 2$ and 40 obese men their mean BMI was $(33.03 \pm 2.41) \mathrm{kg} / \mathrm{m} 2$. Blood samples were collected from all subjects and the level of plasma omentin-1, insulin, total and free testosterone, sex hormone-bonding globulin and $17 \beta$-estradiol were measured by enzyme linked immunossorbent assay (ELISA). Results: Both serum omentin-1 and total testosterone as well as free testosterone were significantly negatively correlated with body mass index, waist circumference, fasting serum glucose, serum insulin and HOMA-IR, and significantly positively correlated with QUICKI and sex hormone-binding globulin. In addition, omentin-1 serum levels correlate positively with free testosterone. Conclusions: Obese men showed significantly higher; body mass index, waist circumference, waist to hip ratio, fasting serum glucose, $2 \mathrm{hr}$ oral glucose tolerance test, serum insulin, HOMA-IR and estradiol, and significantly lower omentin-1, total testosterone, free testosterone and sex hormone-binding globulin as compared to normal group.
\end{abstract}

Keywords: omentin-1, testosterone, insulin resistance, obese men. 


\section{Introduction}

Obesity is a worldwide epidemic that continues to grow at an alarming rate. this condition increases the morbidity and mortality associated with both acute and chronic diseases. some of the deleterious consequences of obesity have been attributed to its induction of low-grade chronic inflammatory state that arises from the production and secretion of inflammatory mediators from the expanded pool of activated adipocytes. $^{(1)}$

The metabolic syndrome is associated with excessive accumulation of central body fat. As well as its role in energy storage, adipose tissue produces several hormones and cytokines termed adipokines that have widespread effects on carbohydrate and lipid metabolism. They appear to play an important role in the pathogenesis of insulin resistance (IR), diabetes, and atherosclerosis.5 Adipose tissue is now hypothesized to be the largest endocrine organ that has widespread effects on carbohydrate and lipid metabolism, secreting a large number of biologically important substances termed adipokines. Furthermore, it is apparent that accumulation of visceral adipose tissue poses a greater cardiometabolic risk than does subcutaneous adipose tissue ${ }^{(2)}$, as removal of visceral but not subcutaneous adipose tissue has been demonstrated to improve insulin sensitivity. (3)

Omentin-1 (also named Omentin, Intelectin-1, Endothelial Lectin HL-1 and Intestinal Lactoferrin Receptor) is a novel fat depot-specific adipokine that was identified from a cDNA library of visceral omental adipose tissue by Yang et al. (4) The mature omentin is a secretory glycoprotein consisting of 295 amino acids and N-linked oligosaccharides, and its basic structural unit is a $120-\mathrm{kDa}$ homotrimer in which 40-kDa polypeptides are bridged by disulfide bonds. Omentin-1 is primarily secreted by stromal vascular cells in visceral adipose tissue, and is expressed to a lesser extent in the heart, lung, and placenta. ${ }^{(5,6)}$ In vitro experiments have revealed that treatment with recombinant omentin-1 enhanced insulin-stimulated glucose uptake in human subcutaneous and omental adipocytes, triggering Akt signaling in both the absence and the presence of insulin. (7) Furthermore, plasma omentin-1 level was inversely correlated with obesity and insulin resistance (IR). ${ }^{(8)}$

In clinical studies, circulating omentin-1 concentrations have been shown to be decreased in patients with obesity, impaired glucose regulation, polycystic ovary syndrome, type 1 diabetes, and type 2 diabetes. (9-13) Low circulating levels of omentin-1 have also been associated with endothelial dysfunction and cardiovascular disease. ${ }^{(14,15)}$ Given these clinical associations, omentin-1 has garnered attention as a possible contributor to the pathogenesis of the metabolic syndrome. ${ }^{(16,17)}$

The aim of the present work was to evaluate the level of serum omentin-1 and its association with serum testosterone and insulin resistance in obese men.

The present study included 60 apparently healthy men. They were classified into two groups:

The normal control groups consist of twenty men, their mean BMI was $(21.51 \pm 2.26) \mathrm{kg} / \mathrm{m}^{2}$ (were chosen from the staff members of MRI), and the obese groups consist of forty men, their mean BMI was $(33.03 \pm 2.41) \mathrm{kg} / \mathrm{m}^{2}$ (were recruited from the Chemical Pathology Medicine Department, Chemical Pathology unit MRI).

The following were done for all participants:

1- Clinical examination

- Through history taking: with special stress on family history of diabetes mellitus and any drug intake.

- Complete physical examination. .

2- Anthropometric measurements

- Body mass index (BMI).

- Waist circumference (WC)

- Waist to hip ratio (WHR).

3- Laboratory measurements

- Fasting and 2hr OGTT glucose level by enzymatic method. ${ }^{(18)}$ 
- Assessment of insulin resistance (IR) ${ }^{(19)}$ and insulin sensitivity ${ }^{(20)}$ by homeostasis model assessment HOMA score (HOMA$\mathrm{IR}=$ Fasting glucose $(\mathrm{mg} / \mathrm{dl}) \times$ Fasting Insulin $(\mu \mathrm{IU} / \mathrm{ml}) / 405)$ and QUICKI respectively.

- Measurement of concentration of insulin ${ }^{(21)}$, omentin-1 ${ }^{(22)}$, total ${ }^{(23)}$ and free ${ }^{(24)}$ testosterone, sex hormone-bonding globulin ${ }^{(25)}$ and $17 \beta$-estradiol ${ }^{(26)}$ were measured in serum by enzyme linked immunosorbent assay.

\section{Results}

\subsection{Results of anthropometric parameters}

The statistical analyses of range and mean \pm $\mathrm{SD}$ values of age, body mass index (BMI), waist circumference (WC), hip circumference (HC), waist/hip ratio (WHR) of normal and obese men were shown in table (1).

For normal men (table 3 ), the mean age was $43.40 \pm 5.66$ year (range $39.0-60.0$ ), the mean BMI was $21.51 \pm 2.26 \mathrm{~kg} / \mathrm{m}^{2}$ (range $18.0-25.0$ ), the mean WC was $86.35 \pm 7.81 \mathrm{~cm}$ (range $69.0-$ 96.0), the mean WHR was $0.89 \pm 0.06$ (range $0.79-1.13)$.

Table 1. The statistical analyses of age (year), body mass index $\left(\mathrm{kg} / \mathrm{m}^{2}\right)$, waist circumference $(\mathrm{cm})$, waist/hip ratio of normal and obese groups

\begin{tabular}{|c|c|c|}
\hline & $\begin{array}{c}\text { Normal group } \\
(\mathrm{n}=\mathbf{2 0})\end{array}$ & $\begin{array}{c}\text { Obese group } \\
(\mathrm{n}=40)\end{array}$ \\
\hline \multicolumn{3}{|l|}{ Age (year) } \\
\hline Range & $39.0-60.0$ & $38.0-57.0$ \\
\hline Mean \pm SD & $43.40 \pm 5.66$ & $44.73 \pm 4.95$ \\
\hline $\mathbf{p}_{1}$ & & $\mathrm{p}_{1}=0.147^{*}$ \\
\hline \multicolumn{3}{|l|}{ BMI $\left(\mathrm{kg} / \mathrm{m}^{2}\right)$} \\
\hline Range & $18.0-25.0$ & $29.5-39.5$ \\
\hline Mean \pm SD & $21.51 \pm 2.26$ & $33.03 \pm 2.41$ \\
\hline $\mathbf{p}_{1}$ & & $\mathrm{p}_{2}<0.001^{*}$ \\
\hline \multicolumn{3}{|l|}{$\mathbf{W C}(\mathrm{cm})$} \\
\hline Range & $69.0-96.0$ & $99.0-121.0$ \\
\hline Mean \pm SD & $86.35 \pm 7.81$ & $110.95 \pm 6.08$ \\
\hline $\mathrm{p}$ & & $\mathrm{p}_{2}<0.001^{*}$ \\
\hline \multicolumn{3}{|l|}{ WHR } \\
\hline Range & $0.79-1.13$ & $0.77-1.34$ \\
\hline Mean \pm SD & $0.89 \pm 0.06$ & $0.95 \pm 0.09$ \\
\hline $\mathrm{p}_{1}$ & & $\mathrm{p}_{1}=0.001$ \\
\hline
\end{tabular}

$\mathrm{p}: \mathrm{p}$ value compared to normal control subjects (independent $\mathrm{T}$ test)

$\mathrm{p}_{1}: \mathrm{p}$ value compared to normal control subjects (Mann-Whitney test)

* : Significantly different from normal control group

Significance was considered at the level of $\mathrm{p} \leq 0.05$

For obese men (table 3 ), the mean age was $44.73 \pm 4.95$ year (range $38.0-57.0$ ), the mean BMI was $33.03 \pm 2.41 \mathrm{~kg} / \mathrm{m}^{2}$ (range $29.5-39.5$ ), the mean WC was $110.95 \pm 6.08 \mathrm{~cm}$ (range 99.0
-121.0 ), the mean WHR was $0.95 \pm 0.09$ (range $0.77-1.34)$.

Data showed a significant difference in BMI, WC and WHR $\left(\mathrm{p}_{1}<0.05\right)$ and insignificant 
difference in age $\left(p_{1}>0.05\right)$ normal and obese men.

\subsection{Biochemical results:}

2.2.1 Results of fasting glucose (FG) (mg/dl), 2hrs serum oral glucose tolerance test glucose (2hrs OGTT glucose) (mg/dl), plasma insulin $(\mu \mathrm{IU} / \mathrm{ml})$, homeostasis model assessment insulin resistance (HOMA-IR) and quantitative insulin sensitivity check index (QUICKI):-

The statistical analyses of range and mean \pm SD values of FG, 2hrs OGTT glucose, plasma insulin, HOMA-IR and QUICKI of normal and obese men were shown in table (2).

For normal men (table 2), the mean FG was $90.85 \pm 6.91 \mathrm{mg} / \mathrm{dl}$ (range $81.0-104.0$ ), the mean 2 hrs OGTT glucose was $84.17 \pm 10.51$ $\mathrm{mg} / \mathrm{dl}$ (range 68.0 - 110.0), the mean plasma insulin was $5.05 \pm 1.89 \mu \mathrm{IU} / \mathrm{ml}$ (range $3.00-$ 11.17), the mean HOMA-IR was $1.14 \pm 0.47$ (range $0.61-2.56$ ) and the mean QUICKI was $0.38 \pm 0.02$ (range $0.33-0.42$ ).

For obese men (table 2), the mean FG was $96.83 \pm 9$. $65 \mathrm{mg} / \mathrm{dl}$ (range $63.0-110.0$ ), the mean 2 hrs OGTT glucose was $101.63 \pm 15.90$ $\mathrm{mg} / \mathrm{dl}$ (range 81.0 - 141.0), the mean plasma insulin was $10.97 \pm 5.61 \mu \mathrm{IU} / \mathrm{ml}$ (range $3.95-$ 28.67), the mean HOMA-IR was $2.61 \pm 1.35$ (range $0.87-6.08$ ) and the mean QUICKI was $0.33 \pm 0.02$ (range $0.29-0.39$ ).

Data showed a significant difference in FG, 2hrs OGTT glucose, insulin levels, HOMA-IR and QUICKI $\left(\mathrm{p}_{1}<0.05\right)$ between normal and obese men.

Table.2. The statistical analyses of fasting glucose (FG) (mg/dl), $2 \mathrm{hrs}$ serum oral glucose tolerance test glucose (2hrs OGTT glucose) $(\mathrm{mg} / \mathrm{dl})$, plasma insulin $(\mu \mathrm{IU} / \mathrm{ml})$, homeostasis model assessment insulin resistance (HOMA-IR) and quantitative insulin sensitivity check index (QUICKI) in normal and obese groups

\begin{tabular}{|c|c|c|}
\hline (2) & $\begin{array}{c}\text { Normal group } \\
(\mathbf{n}=\mathbf{2 0})\end{array}$ & $\begin{array}{c}\text { Obese group } \\
(n=40)\end{array}$ \\
\hline \multicolumn{3}{|l|}{ FG $(\mathrm{mg} / \mathrm{dl})$} \\
\hline Range & $81.0-104.0$ & $63.0-110.0$ \\
\hline Mean \pm SD & $90.85 \pm 6.91$ & $96.83 \pm 9.65$ \\
\hline p & & $\mathrm{p}=0.017^{*}$ \\
\hline \multicolumn{3}{|l|}{ 2hrs OGTT glucose (mg/dl) } \\
\hline Range & $68.0-110.0$ & $81.0-141.0$ \\
\hline Mean \pm SD & $84.17 \pm 10.51$ & $101.63 \pm 15.90$ \\
\hline p & & $\mathrm{p}<0.001^{*}$ \\
\hline \multicolumn{3}{|l|}{ Insulin $(\mu \mathrm{IU} / \mathrm{ml})$} \\
\hline Range & $3.00-11.17$ & $3.95-28.67$ \\
\hline Mean \pm SD & $5.05 \pm 1.89$ & $10.97 \pm 5.61$ \\
\hline $\mathbf{p}$ & & $\mathrm{p}<0.001^{*}$ \\
\hline \multicolumn{3}{|l|}{ HOMA-IR } \\
\hline Range & $0.61-2.56$ & $0.87-6.08$ \\
\hline Mean \pm SD & $1.14 \pm 0.47$ & $2.61 \pm 1.35$ \\
\hline $\mathbf{p}$ & & $\mathrm{p}<0.001^{*}$ \\
\hline \multicolumn{3}{|l|}{ QUICKI } \\
\hline Range & $0.33-0.42$ & $0.29-0.39$ \\
\hline Mean \pm SD & $0.38 \pm 0.02$ & $0.33 \pm 0.02$ \\
\hline $\mathbf{p}$ & & $\mathrm{p}<0.001^{*}$ \\
\hline
\end{tabular}

$\mathrm{p}: \mathrm{p}$ value compared to normal control subjects (independent $\mathrm{T}$ test)

* : Significantly different from normal control group

Significance was considered at the level of $p \leq 0.05$ 


\subsection{Results of serum omentin-1 (ng/l):-}

The statistical analyses of range and mean \pm SD values of serum omentin-1 of normal and obese men were shown in table (3).

For normal men (table 3), the mean omentin-1 was $84.20 \pm 36.43 \mathrm{ng} / \mathrm{l}$ (range 51.78 202.89).

For obese men (table 3), the mean omentin1 was $66.39 \pm 30.24 \mathrm{ng} / \mathrm{l}$ (range $40.75-189.08$ ).

The data showed a significant difference in omentin-1 $(\mathrm{p}<0.05)$ between normal and obese men.
Table 3: The statistical analyses of serum omentin-1 (ng/l) of normal and obese groups

$\mathrm{p}_{1} \quad \mathrm{p}$ value compared to normal control subjects

\begin{tabular}{|c|c|c|}
\hline & $\begin{array}{c}\text { Normal group } \\
(\mathbf{n = 2 0})\end{array}$ & $\begin{array}{c}\text { Obese group } \\
(\mathbf{n = 4 0})\end{array}$ \\
\hline Omentin-1 & & \\
$(\mathrm{ng} / \mathrm{L})$ & & \\
& & \\
Range & $51.78-202.89$ & $40.75-189.08$ \\
Mean \pm SD & $84.20 \pm 36.43$ & $66.39 \pm 30.24$ \\
\hline $\mathbf{p}_{\mathbf{1}}$ & & $\mathrm{p}_{1}=0.002^{*}$ \\
\hline
\end{tabular}

(Mann-Whitney test)

* : Significantly different from normal control group Significance was considered at the level of $p \leq 0.05$

table 4. The statistical analyses of Results of serum total testosterone (TT) (ng/ml), serum free testosterone (FT) (Pg/ml) serum sex hormone binding globulin (SHBG) (nmol/l) and serum estradiol (E2) (Pg/ml) of normal and obese groups

\begin{tabular}{|c|c|c|}
\hline & $\begin{array}{c}\text { Normal group } \\
(\mathbf{n = 2 0})\end{array}$ & $\begin{array}{c}\text { Obese group } \\
(\mathbf{n}=\mathbf{4 0})\end{array}$ \\
\hline Range & & $2.39-6.64$ \\
Mean \pm SD $(\mathrm{ng} / \mathrm{ml})$ & $2.42-10.26$ & $4.37 \pm 1.11$ \\
\hline $\mathbf{p}$ FT $(\mathrm{Pg} / \mathrm{ml})$ & $6.86 \pm 2.11$ & $\mathrm{p}<0.001^{*}$ \\
\hline Range & $28.48-82.36$ & $6.70-63.42$ \\
Mean \pm SD & $57.10 \pm 12.68$ & $44.95 \pm 11.93$ \\
\hline $\mathbf{p}$ & & $\mathrm{P}=0.001^{*}$ \\
\hline SHBG $(\mathrm{nmol} / \mathrm{l})$ & & $11.80-42.20$ \\
Range & $22.20-136.00$ & $26.75 \pm 7.53$ \\
\hline Mean \pm SD & $56.45 \pm 29.82$ & $\mathrm{p}<0.001^{*}$ \\
\hline $\mathbf{p}$ & & $23.0-52.10$ \\
\hline Range & & $37.49 \pm 6.62$ \\
\hline Mean \pm SD & $13.90-54.14$ & $\mathrm{p}=0.004^{*}$ \\
\hline $\mathbf{p}$ & $31.12 \pm 9.65$ & \\
\hline
\end{tabular}

$\mathrm{p}: \mathrm{p}$ value compared to normal control subjects (independent $\mathrm{T}$ test)

$\mathrm{p}_{1}: \mathrm{p}$ value compared to normal control subjects (Mann-Whitney test)

$*$ : Significantly different from normal control group

Significance was considered at the level of $p \leq 0.05$

\subsection{The correlation among the studied clinical and biochemical parameters}

Our results revealed that HOMA-IR was negatively correlated with QUICKI $\left(\mathrm{r}=-0.935^{* *}\right.$, $\mathrm{p}=0.001)$, omentin-1 $(\mathrm{r}=-0.389 * *, \mathrm{p}=0.002)$, TT $(\mathrm{r}=-0.384 * *, \mathrm{p}=0.002), \mathrm{FT}\left(\mathrm{r}=-0.382^{* *}, \mathrm{p}\right.$ $=0.003)$ and SHBG $(\mathrm{r}=-0.498 * *, \mathrm{p}=0.001)$, and positively correlated with BMI $(\mathrm{r}=0.682 * *$, $\mathrm{p}=0.001)$, WC $(\mathrm{r}=0.559 * *, \mathrm{p}=0.001)$, WHR ( $\mathrm{r}$ $\left.=0.285^{* *}, \mathrm{p}=0.027\right), \mathrm{FG}\left(\mathrm{r}=0.316^{*}, \mathrm{p}=0.014\right)$ and SI $\left(\mathrm{r}=0.987^{* *}, \mathrm{p}=0.001\right)$, as illustrated in table (5).

Also, serum omentin-1 was found to be negatively correlated with BMI $\left(\mathrm{r}=-0.423^{* *}, \mathrm{p}=\right.$ 
$0.001), \mathrm{WC}\left(\mathrm{r}=-0.300^{* *}, \mathrm{p}=0.020\right), \mathrm{FG}(\mathrm{r}=-$ $\left.0.334^{* *}, \mathrm{p}=0.009\right)$ and SI $\left(\mathrm{r}=-0.375^{* *}, \mathrm{p}=\right.$ 0.003 ), and positively correlated with QUICKI ( $\mathrm{r}$ $\left.=0.403^{* *}, \mathrm{p}=0.001\right), \mathrm{FT}\left(\mathrm{r}=0.447^{* *}, \mathrm{p}=\right.$ $0.001)$ and SHBG $\left(\mathrm{r}=0.275^{*}, \mathrm{p}=0.034\right)$, as illustrated in table (5).

In addition, serum TT was negatively correlated with BMI $\left(\mathrm{r}=-0.595^{* *}, \mathrm{p}=0.001\right)$, WC $\left(\mathrm{r}=-0.594^{*} *, \mathrm{p}=0.001\right), \mathrm{FG}\left(\mathrm{r}=-0.262^{*}, \mathrm{p}\right.$ $=0.043)$ and SI $\left(\mathrm{r}=-0.368^{* *}, \mathrm{p}=0.004\right)$, and positively correlated with QUICKI $(r=0.440 * *$, $\mathrm{p}=0.001)$, FT $(\mathrm{r}=0.392 * *, \mathrm{p}=0.002)$ and SHBG $\left(\mathrm{r}=0.646^{* *}, \mathrm{p}=0.001\right)$, as illustrated in table (5).

Moreover, serum FT was negatively correlated with BMI $(\mathrm{r}=-0.393 * *, \mathrm{p}=0.002)$, WC $\left(\mathrm{r}=-0.446^{* *}, \mathrm{p}=0.001\right)$, WHR $(\mathrm{r}=-$ $0.399 * *, \mathrm{p}=0.002)$ and SI $\left(\mathrm{r}=-0.366^{* *}, \mathrm{p}=\right.$ 0.004 ), and positively correlated with QUICKI ( $\mathrm{r}$ $\left.=0.348^{* *}, \mathrm{p}=0.006\right)$ and SHBG $\left(\mathrm{r}=0.287^{* *}, \mathrm{p}\right.$ $=0.026)$, as illustrated in table (5).

Table 5. Correlation of plasma RBP-4 levels with clinical and biochemical parameters

\begin{tabular}{|c|c|c|c|c|c|c|c|c|c|c|c|c|c|}
\hline & & BMI & WC & WHR & FG & SI & HOMA-IR & QUICKI & Omentin-1 & TT & FT & SHBG & E2 \\
\hline BMI & $\mathrm{r}$ & 1.000 & $\begin{array}{c}0.798 * * \\
.000 \# \\
\end{array}$ & $\begin{array}{c}0.329 * \\
.010 \# \\
\end{array}$ & $\begin{array}{c}0.441 * * \\
.000 \# \\
\end{array}$ & $\begin{array}{c}0.672 * * \\
.000 \#\end{array}$ & $\begin{array}{c}0.682 * * \\
.000 \# \\
\end{array}$ & $\begin{array}{c}-0.676^{* *} \\
.000 \# \\
\end{array}$ & $\begin{array}{c}-0.423^{* *} \\
.001 \# \\
\end{array}$ & $\begin{array}{c}-0.595^{* *} * \\
.000 \# \\
\end{array}$ & $\begin{array}{c}-0.393 * * \\
.002 \# \\
\end{array}$ & $\begin{array}{c}-0.504 * * \\
.000 \# \\
\end{array}$ & $\begin{array}{c}0.213 \\
.102\end{array}$ \\
\hline WC & $\begin{array}{l}\mathrm{r} \\
\mathrm{p}\end{array}$ & $\begin{array}{c}0.798 * * \\
.000 \# \\
\end{array}$ & 1.000 & $\begin{array}{c}0.605 * * \\
.000 \# \\
\end{array}$ & $\begin{array}{c}0.276 * \\
.033 \# \\
\end{array}$ & $\begin{array}{c}0.554 * * \\
.000 \#\end{array}$ & $\begin{array}{c}0.559 * * \\
.000 \#\end{array}$ & $\begin{array}{c}-0.644 * * \\
.000 \# \\
\end{array}$ & $\begin{array}{c}-0.300^{*} \\
.020 \# \\
\end{array}$ & $\begin{array}{c}-0.594 * * \\
.000 \# \\
\end{array}$ & $\begin{array}{c}-0.446 * * \\
.000 \# \\
\end{array}$ & $\begin{array}{c}-0.503 * * \\
.000 \# \\
\end{array}$ & $\begin{array}{l}0.325^{*} \\
.011 \# \\
\end{array}$ \\
\hline WHR & r & $\begin{array}{c}0.329 * \\
.010 \# \\
\end{array}$ & $\begin{array}{c}0.605 * * \\
.000 \# \\
\end{array}$ & 1.000 & $\begin{array}{c}0.052 \\
.692\end{array}$ & $\begin{array}{c}0.296 * \\
.022 \# \\
\end{array}$ & $\begin{array}{c}0.285 * \\
.027 \# \\
\end{array}$ & $\begin{array}{c}-0.264 * \\
.041 \# \\
\end{array}$ & $\begin{array}{c}-0.224 \\
.085\end{array}$ & $\begin{array}{c}-0.222 \\
.089\end{array}$ & $\begin{array}{c}-0.399 * * \\
.002 \# \\
\end{array}$ & $\begin{array}{c}-0.194 \\
.138\end{array}$ & $\begin{array}{c}0.141 \\
.282\end{array}$ \\
\hline FG & $\mathrm{r}$ & $\begin{array}{c}0.441 * * \\
.000 \#\end{array}$ & $\begin{array}{c}0.276 * \\
.033 \#\end{array}$ & $\begin{array}{c}0.052 \\
.692\end{array}$ & 1.000 & $\begin{array}{l}0.183 \\
.162\end{array}$ & $\begin{array}{c}0.316^{*} \\
.014 \#\end{array}$ & $\begin{array}{c}-0.412 * * \\
.001 \# \\
\end{array}$ & $\begin{array}{c}-0.334 * * \\
.009 \# \\
\end{array}$ & $\begin{array}{c}-0.262^{*} \\
.043 \# \\
\end{array}$ & $\begin{array}{c}-0.078 \\
.551\end{array}$ & $\begin{array}{c}-0.315^{*} \\
.014 \# \\
\end{array}$ & $\begin{array}{c}-0.022 \\
.870\end{array}$ \\
\hline SI & $\mathrm{r}$ & $\begin{array}{c}0.672 * * \\
.000 \#\end{array}$ & $\begin{array}{c}0.554 * * \\
.000 \#\end{array}$ & $\begin{array}{c}0.296 * \\
.022 \# \\
\end{array}$ & $\begin{array}{c}0.183 \\
.162\end{array}$ & 1.000 & $\begin{array}{c}0.987 * * \\
.000 \#\end{array}$ & $\begin{array}{c}-0.916^{* *} \\
.000 \# \\
\end{array}$ & $\begin{array}{c}-0.375^{*} * \\
.003 \# \\
\end{array}$ & $\begin{array}{c}-0.368 * * \\
.004 \# \\
\end{array}$ & $\begin{array}{c}-0.366^{* * *} \\
.004 \# \\
\end{array}$ & $\begin{array}{c}-0.465 * * \\
.000 \# \\
\end{array}$ & $\begin{array}{c}0.075 \\
.567\end{array}$ \\
\hline $\begin{array}{l}\text { HOMA- } \\
\text { IR }\end{array}$ & $\mathrm{r}$ & $\begin{array}{c}0.682 * * \\
.000 \# \\
\end{array}$ & $\begin{array}{c}0.559 * * \\
.000 \# \\
\end{array}$ & $\begin{array}{c}0.285^{*} \\
.027 \# \\
\end{array}$ & $\begin{array}{c}0.316^{*} \\
.014 \# \\
\end{array}$ & $\begin{array}{c}0.987 * * \\
.000 \# \\
\end{array}$ & 1.000 & $\begin{array}{c}-0.935^{* *} \\
.000 \# \\
\end{array}$ & $\begin{array}{c}-0.389 * * \\
.002 \# \\
\end{array}$ & $\begin{array}{c}-0.384 * * \\
.002 \# \\
\end{array}$ & $\begin{array}{c}-0.382 * * \\
.003 \# \\
\end{array}$ & $\begin{array}{c}-0.498 * * \\
.000 \# \\
\end{array}$ & $\begin{array}{c}0.050 \\
.702 \\
\end{array}$ \\
\hline QUICKI & $\begin{array}{l}\mathrm{r} \\
\mathrm{p}\end{array}$ & $\begin{array}{c}-0.676^{*} * \\
.000 \# \\
\end{array}$ & $\begin{array}{c}-0.644 * * \\
.000 \#\end{array}$ & $\begin{array}{c}-0.264 * \\
.041 \#\end{array}$ & $\begin{array}{c}-0.412 * * \\
.001 \#\end{array}$ & $\begin{array}{c}-0.916 * * \\
.000 \# \\
\end{array}$ & $\begin{array}{c}-0.935 * * \\
.000 \# \\
\end{array}$ & 1.000 & $\begin{array}{c}0.403 * * \\
.001 \#\end{array}$ & $\begin{array}{c}0.440 * * \\
.000 \#\end{array}$ & $\begin{array}{c}0.348 * * \\
.006 \#\end{array}$ & $\begin{array}{c}0.485^{*} * \\
.000 \#\end{array}$ & $\begin{array}{c}-0.183 \\
.161\end{array}$ \\
\hline $\begin{array}{l}\text { Omentin } \\
-1\end{array}$ & $\begin{array}{l}\mathrm{r} \\
\mathrm{p}\end{array}$ & $\begin{array}{c}-0.423 * * \\
.001 \#\end{array}$ & $\begin{array}{c}-0.300 * \\
.020 \#\end{array}$ & $\begin{array}{c}-0.244 \\
.085\end{array}$ & $\begin{array}{c}-0.334 * * \\
.009 \#\end{array}$ & $\begin{array}{c}-0.375 * * \\
.003 \# \\
\end{array}$ & $\begin{array}{c}-0.389 * * \\
.002 \#\end{array}$ & $\begin{array}{c}0.403 * * \\
.001 \#\end{array}$ & $\overline{1.000}$ & $\begin{array}{c}0.148 \\
.259\end{array}$ & $\begin{array}{c}0.447 * * \\
.000 \#\end{array}$ & $\begin{array}{c}0.275^{*} \\
.034 \#\end{array}$ & $\begin{array}{c}-0.194 \\
.138\end{array}$ \\
\hline TT & $\begin{array}{l}\mathrm{r} \\
\mathrm{p}\end{array}$ & $\begin{array}{c}-0.595^{*} * \\
.000 \# \\
\end{array}$ & $\begin{array}{c}-0.594 * * \\
.000 \# \\
\end{array}$ & $\begin{array}{c}-0.222 \\
.089\end{array}$ & $\begin{array}{c}-0.262 * \\
.043 \#\end{array}$ & $\begin{array}{c}-0.368 * * \\
.004 \#\end{array}$ & $\begin{array}{c}-0.384 * * \\
.002 \#\end{array}$ & $\begin{array}{c}0.440 * * \\
.000 \#\end{array}$ & $\begin{array}{c}0.148 \\
.259\end{array}$ & 1.000 & $\begin{array}{c}0.392 * * \\
.002 \#\end{array}$ & $\begin{array}{c}0.646 * * \\
.000 \#\end{array}$ & $\begin{array}{c}0.073 \\
.580\end{array}$ \\
\hline FT & $\mathrm{r}$ & $\begin{array}{c}-0.393 * * \\
.002 \# \\
\end{array}$ & $\begin{array}{c}-0.446 * * \\
.000 \# \\
\end{array}$ & $\begin{array}{c}-0.399 * * \\
.002 \# \\
\end{array}$ & $\begin{array}{c}-0.078 \\
.551\end{array}$ & $\begin{array}{c}-0.366 * * \\
.004 \# \\
\end{array}$ & $\begin{array}{c}-0.382 * * \\
.003 \# \\
\end{array}$ & $\begin{array}{c}0.348 * * \\
.006 \# \\
\end{array}$ & $\begin{array}{c}0.447 * * \\
.000 \# \\
\end{array}$ & $\begin{array}{c}0.392 * * \\
.002 \# \\
\end{array}$ & 1.000 & $\begin{array}{c}0.287 * \\
.026 \# \\
\end{array}$ & $\begin{array}{c}-0.057 \\
.663\end{array}$ \\
\hline SHBG & r & $\begin{array}{c}-0.504^{*} * \\
.000 \# \\
\end{array}$ & $\begin{array}{c}-0.503 * * \\
.000 \# \\
\end{array}$ & $\begin{array}{c}-0.194 \\
.138\end{array}$ & $\begin{array}{c}-0.315^{*} \\
.014 \# \\
\end{array}$ & $\begin{array}{c}-0.465^{*} * \\
.000 \# \\
\end{array}$ & $\begin{array}{c}-0.498 * * \\
.000 \# \\
\end{array}$ & $\begin{array}{c}0.485 * * \\
.000 \#\end{array}$ & $\begin{array}{c}0.275 * \\
.034 \# \\
\end{array}$ & $\begin{array}{c}0.646^{*} * \\
.000 \#\end{array}$ & $\begin{array}{c}0.287 * \\
.026 \# \\
\end{array}$ & 1.000 & $\begin{array}{c}-0.153 \\
.243\end{array}$ \\
\hline E2 & $\mathrm{r}$ & $\begin{array}{c}0.213 \\
.102 \\
\end{array}$ & $\begin{array}{c}0.325^{*} \\
.011 \# \\
\end{array}$ & $\begin{array}{c}0.141 \\
.282\end{array}$ & $\begin{array}{c}-0.022 \\
.870\end{array}$ & $\begin{array}{c}0.075 \\
.567\end{array}$ & $\begin{array}{c}0.050 \\
.702\end{array}$ & $\begin{array}{c}-0.183 \\
.161\end{array}$ & $\begin{array}{c}-0.194 \\
.138\end{array}$ & $\begin{array}{c}0.073 \\
.850\end{array}$ & $\begin{array}{c}-0.075 \\
.663\end{array}$ & $\begin{array}{c}-0.153 \\
.243\end{array}$ & 1.000 \\
\hline
\end{tabular}

$\mathbf{r} \quad$ :Pearson coefficient $\quad \mathbf{r}_{\mathrm{s}}$ : Spearman coefficient

** . Correlation is significant at the 0.01 level (2-tailed).

* . Correlation is significant at the 0.05 level (2-tailed).

\# : Statistically significant at $\mathrm{p} \leq 0.05$

\section{Discussion}

Over the last two decades, the prevalence of overweight or obesity in the world has increased at an accelerating and alarming rate. Obesity is closely linked to a wide array of pathophysiologic consequences including insulin resistance (IR), type 2 diabetes mellitus (T2DM), hypertension, hyperlipidemia and atherosclerosis. (27) The association of obesity with T2DM has been recognized for decades, and the major basis for this link is the ability of obesity to engender IR. But not all obese have IR or diabetes, not all fat deposits contribute to this disease. ${ }^{(27)}$ Banerji 
and his colleagues discovered that fat distribution in the body is important for the progress of the disease. (28) Thus, visceral fat in central or visceral obesity, mainly composed of omental and mesenteric fat and retroperitoneal fat, ${ }^{(29)}$ is more important in relation to IR than subcutaneous fat and the reduction in visceral fat can increase the sensitivity of insulin. ${ }^{(28,29)}$ In clinical studies waist circumference and waist-tohip ratio are closely correlated with visceral fat content. ${ }^{(30,31)}$ In the present study, BMI, WC and WHR were significantly higher in obese group as compared to normal group.

In the present study, it was noticed that glucose and the two proxy parameters of IR, ${ }^{(32-34)}$ SI and HOMA-IR, were significantly higher in obese than in normal group and significantly positively correlated with WC,WHR and BMI. This result is expected and confirmed by Kahn and his colleagues, who reported that obesity is a major cause of IR. ${ }^{(35)}$

As for the mechanism linking obesity and IR, FFAs role is preferentially considered because it has ever been suggested to be a main underlying cause of IR. In obesity, FFAs released from visceral fat to the liver via portal vein are more than those released from subcutaneous fat, ${ }^{(36)}$ which could decrease the sensitivity of insulin in the liver and exert dysfunction in the liver via several mechanisms, including stimulation of gluconeogenesis and / or fatty acid oxidation. ${ }^{(27)}$ So FFAs have been suggested to be a main underlying mechanism of IR in obesity. (37)

FFAs are not sufficient to account for the mechanism from obesity to IR. However, further studies were done demonstrating that visceral obesity affects the release of certain cytokines from macrophages infiltrating into the fat, particularly increasing the release of tumor necrosis factor- $\alpha$ (TNF- $\alpha$ ), IL-6, resistin and plasminogen activator inhibitor-1. Elevated TNF$\alpha$ in adipose tissue is known to contribute to IR along with IL-6, a cytokine that is elevated in both obesity and T2DM. IL-6 reduces insulin sensitivity by inhibiting insulin receptor signal transduction in tissue. ${ }^{(38,39}$
Therefore we hypothesis that adipocytokines may be a bridge connecting obesity and IR, and visceral fat in obesity also could be a primer for IR.

When visceral fat accumulates, just like a primer, in visceral obesity it should begin to display unhealthy effect which begin to take place in the body. In addition to it, as one of physiological regulation mechanisms of the body, most of the adipocytokines from the visceral fat reduce the visceral fat volume. Actually, on the contrary, with a change in the serum adipocytokine level and an imbalance of them in the body for a long term, it will become a pathological condition and various kinds of effects may leads to the formation of new pathogenesis and new therapeutic approach to IR. (27)

White adipose tissue is a major secretory and endocrine organ that secretes $\sim 30$ biologically active peptides and proteins that can be grouped either adipose derived hormones (for example leptin, adiponectin, and resistin) or adipokines (immune modulating agents) such omentin. ${ }^{(40)}$

Omentin is recently discovered novel adipokine. ${ }^{(41)}$ Its physiological role in human remain largely unknown. (22) The goal of this study was to evaluate the levels of serum omentin-1 and its association with serum testosterone and IR in obese men. Therefore we planned to analyze the relationship of serum omentin-1 with some parameters of adiposity (WC,WHR, BMI), IR parameters (glucose, SI, HOMA-IR), and hormonal profile (TT, FT, $\beta$ estradiol, SHBG).

In the present study, it was found that serum omentin-1 levels in obese group, were lower than normal subjects. Additionally serum omentin-1 concentration were negatively correlated with WC and BMI. The data suggests that some aspects of obesity negatively regulates omentin-1 expression and release into the circulation. This result is in agreement with the report of De Souza Batista, (42) demonstrating that obesity is an important factor to induce the omentin-1 reduction.

Although the data clearly supports the regulation of omentin-1 by obesity, omentin-1 
may also be regulated by inflammation. Other studies have shown that omentin-1 expression is altered in inflammatory states. ${ }^{(43,44)}$ Obesity itself is associated with low levels of chronic inflammation, which may contribute to the regulation in the role of omentin-1 in human physiology. ${ }^{(45,46)}$

Furthermore, the lower omentin-1 levels observed in this study may suggest the dysregulation of omentin-1 in biosynthesis or in response to hyperglycemia and hyperinsulinemia in obese group. Tan and his colleagues (47) reported that insulin and glucose significantly and dose-dependently decreased omentin mRNA expression and omentin protein production in omental adipose tissue explants, and that hyperinsulinemia significantly reduced serum omentin-1 levels in healthy subjects. It may be that serum glucose and insulin levels regulate omentin-1 synthesis directly or indirectly.

In the current study, a negative significant correlation of omentin-1 levels with glucose, insulin and HOMA-IR index, and positive correlation with QUICKI were observed. Previous in vitro studies demonstrated that omentin-1 increases insulin signal transduction by activating the protein kinase $\mathrm{B}^{(48)}$ and enhances insulin-mediated glucose transport in adipocytes. ${ }^{(4)}$ We speculate that the decreased serum omentin-1 concentration observed in obese group may cause a reduction of insulinstimulated glucose uptake in visceral and subcutaneous adipocytes or other insulin sensitive tissues. Accordingly we can predict that lack of omentin-1 may contribute to IR.

Obesity has been associated with various endocrine abnormalities both in men and women. $(50,51)$ in this study, it was noticed that the reproductive hormonal profile of obese men deviate from what is considered the norm. TT, FT and SHBG were significantly lower in obese as compared to normal group whereas $\beta$-oesteradiol was higher. Moreover, TT, FT and SHBG were negatively correlated with anthropometric indices (BMI and WC), and FT negatively correlated with WHR. These results are supported by other studies. Allan et al ${ }^{(52)}$ demonstrated that changes in visceral fat appeared to be a function of changes in serum testosterone levels, and prospective studies ${ }^{(53)}$ confirm that lower androgen predict central adiposity in men. Furthermore, longitudinal epidemiological data demonstrate that relatively low testosterone levels are a risk factor for development of visceral obesity. ${ }^{(54)}$

Testosterone is a lipophilic hormone, its transportation in blood requires binding to plasma proteins, primarily sex hormone binding globulin (SHBG). (55) The reduced level of SHBG concentration reduced in this study and its inverse relation to visceral obesity (BMI, WC) can explain the significant reduction of circulating testosterone in obese subjects. the cause of reduced SHBG is thought to be due to higher circulating insulin concentration detected in obese subjects as basal secretion of SHBG by cultured human hepatoma cell line (HepG2) was greatly reduced by the physiological concentration of insulin. ${ }^{(56-58)}$ Previous studies showed that, in vivo diazoxide treatment, resulting in decreased insulin levels, produces a significant increase in SHBG, ${ }^{(59)}$ whereas SHBG levels decrease actually during hyperinsulinemic euglycemic clamp studies together, these intervention studies suggest that insulin negatively regulates hepatic production of SHBG. (60)

It has been suggested that the increase in adipose tissue in obese may results in increased release of pro-inflammatory cytokines such as TNF- $\alpha$ and IL-1. ${ }^{(61)}$ Cytokines inhibit testosterone production primarily through actions on the testis. TNF- $\alpha$ inhibit steroidogenesis in Leydig cells at the transcriptional level. It has been suggested that NF-kB, a nuclear factor activated by TNF- $\alpha$, inhibits the transactivation of orphan nuclear receptors that mediate the expression of steroidogenic-enzyme genes. ${ }^{(62)}$ IL-1 has also been found to inhibit cholesterol side chain cleavage by cytochrome P450 in Leydig cells. (63)

Although it is well established testosterone biosynthesis is regulated primarily by pulsatile secretion of $\mathrm{LH}$, there is compelling evidence that Leydig cell steroidogenesis is also modulatedby circulating and / or locally produced hormones. ${ }^{(64)}$ Insulin receptors are present on Leydig cells, and insulin stimulate testosterone production in Leydig cell cultures. ${ }^{(65)}$ These in vitro data seem 
to be at variance with the demonstration in our study that high insulin levels are inversely correlated with serum testosterone levels. However, we hypothesized that IR states such as obesity, Leydig cell steroidogenesis is impaired because of target organ resistant to insulin action.

In addition, obese group have been shown to have elevated levels of $\beta$-oestradiol than normal group. This estrogen excess is explained by over activity of the aromatase cytochrome P450 enzyme, which is expressed at high levels in white adipose tissue and is responsible for a key step in the biosynthesis of estrogen. ${ }^{(66)}$ An increase in $\beta$-oestradiol concentration would lead to the suppression of hypothalamic gonadotropinreleasing hormone and pituitary gonadotropin secretion. ${ }^{(67)}$ Thus would result in the reduction of testosterone secretion by Leydig cells.

Furthermore, it was found that total and free testosterone correlate negatively with insulin and HOMA-IR and positively with QUICKI, this results is consistent with that reported by Tsai et al $^{(33)}$ and Pilleloud et al. ${ }^{(68)}$

One mechanism by which testosterone via androgen receptor might facilitate insulin sensitivity is by regulating the expression of insulin dependent proteins, and dose-dependent effects of testosterone on insulin receptor substrate-1 (IRS-1) and glucose transporter4(GLUT-4) have been documented in cell models. ${ }^{(69,70)}$ Thus the low levels of testosterone may throw light on the possibility of decreasing insulin sensitivity in obese subjects.

Moreover, previous studies demonstrated that testosterone correlate positively with genetic and functional mitochondrial indices of increased insulin sensetivity in human skeltal muscle, ${ }^{68,71,72)}$ and in male rats castration increases IR by decreasing muscular glucose uptake. ${ }^{(73)}$ Recent microarray studies in mice have shown that testosterone regulates skeltal muscule genes involved in glucose metabolism in ways that would be expected to decrease systemic IR. ${ }^{(74,75)}$ In view of these studies it could predicted that decreased levels of testosterone detected in our data may cause mitochondrial dysfunction leading to decreased lipid oxidation, ectopic TG accumulation and ultimatly to IR.
Also, testosterone inhibits lipoprotein lipase enzyme (LPL) in abdominal adipose tissue, leading to decreased TG uptake in central fat depots. (76) This low testosterone levels detected in the present study may predispose to viseral obesity, leading to dysregulation of fatty acid metabolism, which in turn promotes IR.

In obese men, hypoandrogenism is an early marker of glucose metabolism and insulin alteration, which may progress toward a metabolic syndrome, or to an overt diabetes.

The results of the present study revealed that testosterone which is positively correlated with insulin sensitivity may be considered as one of the contributing factor for the development of IR in obese subjects. Moreover, reduced levels of omentin-1 observed in this study may also be attributed to hyperinsulinemia, and its correlation with FT may point to the possible effect of FT on circulating omentin-1 levels.

\section{Conclusion}

- As compared to normal group, body mass index, waist circumference, waist to hip ratio, fasting serum glucose, $2 \mathrm{hr}$ oral glucose tolerance test, serum insulin and HOMA-IR and estradiol were significantly higher, while omentin-1, total testosterone, free testosterone and sex hormone-binding globulin were significantly lower in obese subjects.

- Both serum omentin-1 and total testosterone as well as free testosterone were significantly negatively correlated with body mass index, waist circumference, fasting serum glucose, serum insulin and HOMAIR, and significantly positively correlated with QUICKI and sex hormone-binding globulin. In addition, omentin-1 serum levels correlate positively with free testosterone.

- Serum omentin-1 levels was significantly decreased in obese men, omentin- 1 could be used as a biological marker for insulin resistance in obese. In addition the close relationship between serum omentin-1 levels and free testosterone levels may suggest that 
the regulation of omentin-1 might be dependent on free testosterone levels.

\section{References}

1- Vachharajani V, Granger DN. Adipose tissue: a motor for the inflammation associated with obesity. IUBMB Life 2009;61:424-30. DOI: $\underline{10.1002 / i u b .169}$

2- Wajchenberg BL. Subcutaneous and visceral adipose tissue: their relation to the metabolic syndrome. Endocrine Reviews 2000; 21: 697-738. DOI: 10.1210/edrv.21.6.0415

3- Thorne A, Lonnqvist F, Apelman J, Hellers G, Arner P. A pilot study of long-term effects of a novel obesity treatment: omentectomy in connection with adjustable gastric banding. International Journal of Obesity and Related Metabolic Disorders 2002;26: 193-199. DOI: $\underline{10.1038 / \text { sj.ijo.0801871 }}$

4- Yang RZ, Lee MJ, Hu H, Pray J,Wu HB, Hansen BC, Shuldiner AR, Fried SK, McLenithan JC, Gong DW. Identification of omentin as a novel depotspecific adipokine in human adipose tissue: possible role in modulating insulin action. American Journal of Physiology. Endocrinology and Metabolism 2006;290: 1253-1261. DOI: 10.1152/ajpendo.00572.2004

5- Schaffler A, Neumeier M, Herfarth H, Furst A, Scholmerich J, Buchler C. Genomic structure of human omentin, a new adipocytokine expressed in omental adipose tissue. Biochim Biophys Acta 2005;1732:96102. DOI: 10.1016/j.bbaexp.2005.11.005

6- Vu A, Sidhom MS, Bredbeck BC, Kosmiski LA, Aquilante CL. Evaluation of the relationship between circulating omentin-1 concentrations and components of the metabolic syndrome in adults without type 2 diabetes or cardiovascular disease. Diabetol Metabol Synd 2014;6:4-12. DOI: $\underline{\text { 10.1186/1758-5996-6-4 }}$

7- Choi JH, Rhee EJ, Kim KH, Woo HY, Lee WY, Sung KC. Plasma omentin-1 levels are reduced in non-obese women with normal glucose tolerance and polycystic ovary syndrome. Eur J Endocrinol 2011;165:78996. DOI: 10.1530/EJE-11-0375

8- Catli G, Anik A, Abaci A, Kume T, Bober E. Low omentin-1 levels are related with clinical and metabolic parameters in obese children. Exp Clin Endocrinol Diabet 2013;121:595-600. DOI: 10.1055/s-0033$\underline{1355338}$

9- Auguet T, Quintero Y, Riesco D, Morancho B, Terra X, Crescenti A, Broch M, Aguilar C, Olona M, Porras JA, Hernandez M, Sabench F, del Castillo D, Richart C. New adipokines vaspin and omentin. Circulating levels and gene expression in adipose tissue from morbidly obese women. BMC Med Genet 2011;12:60. DOI: 10.1186/1471-2350-12-60

10- Pan HY, Guo L, Li Q. Changes of serum omentin-1 levels in normal subjects and in patients with impaired glucose regulation and with newly diagnosed and untreated type 2 diabetes. Diab Res Clin Pract 2010;88:2933. DOI: 10.1016/j.diabres.2010.01.013

11- Tan BK, Adya R, Farhatullah S, Lewandowski $\mathrm{KC}$, O'Hare $\mathrm{P}$, Lehnert $\mathrm{H}$, Randeva HS. Omentin-1, a novel adipokine, is decreased in overweight insulin-resistant women with polycystic ovary syndrome: ex vivo and in vivo regulation of omentin-1 by insulin and glucose. Diabetes 2008;57:801808. DOI: $10.2337 / \mathrm{db} 07-0990$

12- Yan P, Liu D, Long M, Ren Y, Pang J, Li R. Changes of serum omentin levels and relationship between omentin and adiponectin concentrations in type 2 diabetes mellitus. Exp Clin Endocrinol Diabet 2011;119:257-263. DOI: 10.1055/s-0030$\underline{1269912}$

13- Tan BK, Pua S, Syed F, Lewandowski KC, O'Hare JP, Randeva HS. Decreased plasma omentin-1 levels in Type 1 diabetes mellitus. Diabet Med 2008 ;25:1254-1255. DOI: 10.1111/j.1464-5491.2008.02568.x

14- Moreno-Navarrete JM, Ortega F, Castro A, Sabater M, Ricart W, Fernandez-Real JM. Circulating omentin as a novel biomarker of endothelial dysfunction. Obesity 2011;19:1552-1559. DOI: 10.1038/oby.2010.351 
15- Shibata R, Ouchi N, Kikuchi R, Takahashi R, Takeshita K, Kataoka Y, Ohashi K, Ikeda N, Kihara S, Murohara T. Circulating omentin is associated with coronary artery disease in men. Atherosclerosis 2011;219:811-814. DOI: 10.1016/j.atherosclerosis.2011.08.017

16- Shang FJ, Wang JP, Liu XT, Zheng QS, Xue YS, Wang B, Zhao LY. Serum omentin-1 levels are inversely associated with the presence and severity of coronary artery disease in patients with metabolic syndrome. Biomarkers 2011;16:657-662. DOI: 10.3109/1354750X.2011.622789

17- Jialal I, Devaraj S, Kaur H, Adams-Huet B, Bremer AA. Increased chemerin and decreased omentin-1 in both adipose tissue and plasma in nascent metabolic syndrome. $\mathbf{J}$ Clin Endocrinol Metab 2013;98:E514-517. DOI: $10.1210 /$ jc. 2012-3673

18-Trinder P. Blood glucose estimation. In: Practical Clinical Biochemistry. Varley $\mathrm{H}$, Gowenlock AH, Bell M (eds). 5th ed. Heinemann Medical Books, London.1988, p.321.

19-Starr JI, Mako ME, Juhn D, Rubenstein AH. Measurement of serum proinsulin-like material: cross-reactivity of porcine and human proinsulin in the insulin radioimmunoassay. $\mathrm{J}$ Lab Clin Med 1978;91:683-92.

20-Talaei A, Mohamadi M, Adgi Z. The effect of vitamin $D$ on insulin resistance in patients with type 2 diabetes. Diabetol Metab Syndr 2013;5:8. DOI: 10.1186/1758-5996-5-8

21-Katz A, Nambi SS, Mather K, Baron AD, Follmann DA, Sullivan G, Quon MJ. Quantitative insulin sensitivity check index: a simple, accurate method for assessing insulin sensitivity in humans. J Clin Endocrinol Metab 2000;85:2402-10. DOI: 10.1210/jcem.85.7.6661

22- Pan HY, Guo L, Li Q. Changes of serum omentin-1 levels in normal subjects and in patients with impaired glucose regulation and with newly diagnosed and untreated type 2 diabetes. Diabetes Res Clin Pract 2010;88:29-33. $\underline{10.1016 / \text { j.diabres.2010.01.013 }}$
23-Burtis CA, Ashwood ER, Bruns De. Tietz fundamental of clinical chemistry. 6th ed. Elsevier Saunders Company, St Louis..2008, p.784.

24-Winters SJ, Kelley DE, Goodpaster B. The analog free testosterone assay: are the results in men clinically useful? Clin Chem 1998;44:2178-82.

25-Selby C. Sex hormone binding globulin: origin, function and clinical significance. Ann Clin Biochem 1990;27:532-41. DOI: 10.1177/000456329002700603

26- Burtis CA, Ashwood ER, Bruns De. Tietz fundamental of clinical chemistry. 4th ed. Elsevier Saunders Company, St Louis..2006, pp.2134-6.

27- Zhuang XF, Zhao MM, Weng CL, Sun NL. Adipocytokines: a bridge connecting obesity and insulin resistance. Med Hypotheses 2009;73:981-5. DOI: 10.1016/j.mehy.2009.05.036

28- Banerji MA, Faridi N, Atluri R, Chaiken RL, Lebovitz HE. Body composition, visceral fat, leptin, and insulin resistance in Asian Indian men. $\mathbf{J}$ Clin Endocrinol Metab 1999;84:137-44. DOI: 10.1210/jc.84.1.137

29- Maki KC, Rains TM, Bell M, Reeves MS, Farmer MV, Yasunaga K. Fat mass, abdominal fat distribution, and C-reactive protein concentrations in overweight and obese men and women. Metab Syndr Relat Disord 2011;9:291-6. DOI: 10.1089/met.2010.0132

30-Weits T, van der Beek EJ, Wedel M, Ter Haar Romeny BM. Computed tomography measurement of abdominal fat deposition in relation to anthropometry. Int $\mathrm{J}$ Obes 1988;12:217-25.

31-Semiz S, Ozgören E, Sabir N. Comparison of ultrasonographic and anthropometric methods to assess body fat in childhood obesity. Int J Obes 2007;31:53-8. DOI: 10.1038/sj.ijo.0803414

32- Hanson RL, Pratley RE, Bogardus C, Narayan KM, Roumain JM, Imperatore G, Fagot-Campagna A, Pettitt DJ, Bennett PH, Knowler WC. Evaluation of simple indices of insulin sensitivity and insulin secretion for use in epidemiologic studies. Am J 
Epidemiol 2000;151:190-8. DOI: 10.1093/oxfordjournals.aje.a010187

33- Tsai EC, Matsumoto AM, Fujimoto WY, Boyko EJ. Association of bioavailable, free, and total testosterone with insulin resistance: influence of sex hormone-binding globulin and body fat. Diabetes Care 2004;27:861-8. DOI: 10.2337/diacare.27.4.861

34- Li C, Ford ES, Li B, Giles WH, Liu S. Association of testosterone and sex hormone-binding globulin with metabolic syndrome and insulin resistance in men. Diabetes Care 2010;33:1618-24. DOI: 10.2337/dc09-1788

35- Kahn BB, Flier JS. Obesity and insulin resistance. J Clin Invest 2000;106:473-481. DOI: $10.1172 / \mathrm{JCI} 10842$

36- Björntorp P. "Portal" adipose tissue as a generator of risk factors for cardiovascular disease and diabetes. Arteriosclerosis 1990;10:493-6.

DOI: 10.1161/01.ATV.10.4.493

37- Bergman RN, Ader M. Free fatty acids and pathogenesis of type 2 diabetes mellitus. Trends Endocrinol Metab 2000;11:351-6. DOI: 10.1016/S1043-2760(00)00323-4

38- Guzik TJ, Mangalat D, Korbut R. Adipocytokines - novel link between inflammation and vascular function? J Physiol Pharmacol 2006;57:505-28.

39- de Luca C, Olefsky JM. Inflammation and insulin resistance. FEBS Lett 2008;582:97105. DOI: 10.1016/j.febslet.2007.11.057

40- Athyros VG, Tziomalos K, Karagiannis A, Anagnostis P, Mikhailidis DP. Should adipokines be considered in the choice of the treatment of obesity-related health problems? Curr Drug Targets 2010;11:12235. DOI: $10.2174 / 138945010790030992$

41- Moreno-Navarrete JM1, Ortega F, Castro A, Sabater M, Ricart W, Fernández-Real JM. Circulating omentin as a novel biomarker of endothelial dysfunction. Obesity (Silver Spring) 2011;19:1552-9. DOI: 10.1038/oby.2010.351

42- de Souza Batista CM, Yang RZ, Lee MJ, Glynn NM, Yu DZ, Pray J, Ndubuizu K, Patil S, Schwartz A, Kligman M, Fried SK, Gong DW, Shuldiner AR, Pollin TI,
McLenithan JC. Omentin plasma levels and gene expression are decreased in obesity. Diabetes 2007; 56:1655-1661. DOI: 10.2337/db06-1506

43- Heilbronn LK, Noakes M, Clifton PM. Energy Restriction and Weight Loss on Very-Low-Fat Diets Reduce C-Reactive Protein Concentrations in Obese, Healthy Women. Arterioscler Thromb Vasc Biol 2001;21: $\quad 968-970 . \quad$ DOI: 10.1161/01.ATV.21.6.968

44- Ryan AS, Nicklas BJ. Reductions in plasma cytokine levels with weight loss improve insulin sensitivity in overweight and obese postmenopausal women. Diabetes Care 2004:27:1699-705. 10.2337/diacare.27.7.1699

45- Weisberg SP, McCann D, Desai M, Rosenbaum M, Leibel RL, Ferrante AW Jr. Obesity is associated with macrophage accumulation in adipose tissue. $\mathrm{J}$ Clin Invest 2003; 112:1796-808. 10.1172/JCI200319246

46- Kuperman DA, Lewis CC, Woodruff PG, Rodriguez MW, Yang YH, Dolganov GM, Fahy JV, Erle DJ. Dissecting asthma using focused transgenic modeling and functional genomics. J Allergy Clin Immunol 2005;116:305-11. DOI: 10.1016/j.jaci.2005.03.024

47- Tan BK, Adya R, Farhatullah S, Lewandowski $\mathrm{KC}$, O'Hare P, Lehnert $\mathrm{H}$, Randeva HS. Omentin-1, a novel adipokine, is decreased in overweight insulin-resistant women with polycystic ovary syndrome: ex vivo and in vivo regulation of omentin-1 by insulin and glucose. Diabetes 2008;57:801-8. DOI: 10.2337/db07-0990

48- Qureshi K, Abrams GA. Metabolic liver disease of obesity and role of adipose tissue in the pathogenesis of nonalcoholic fatty liver disease. World J Gastroenterol 2007;13:3540-53. DOI: 10.3748/wjg.v13.i26.3540

49-Moreno-Navarrete JM, Catalán V, Ortega F, Gómez-Ambrosi J, Ricart W, Frühbeck G, Fernández-Real JM. Circulating omentin concentration increases after weight loss. 
Nutr Metabol 2010; 7:27. DOI: 10.1186/1743-7075-7-27

50- Kokkoris P, Pi-Sunyer FX. Obesity and endocrine disease. Endocrinol Metab Clin North Am 2003;32:895-914. DOI: 10.1016/S0889-8529(03)00078-1

51- Janković D, Wolf $\mathrm{P}$, Anderwald $\mathrm{CH}$, Winhofer Y, Promintzer-Schifferl M, Hofer A, Langer F, Prager G, Ludvik B, Gessl A, Luger A, Krebs M. Prevalence of endocrine disorders in morbidly obese patients and the effects of bariatric surgery on endocrine and metabolic parameters. Obes Surg 2012;22:62-9. DOI: 10.1007/s11695-0110545-4

52- Allan CA, Strauss BJ, Burger HG, Forbes EA, McLachlan RI. Testosterone therapy prevents gain in visceral adipose tissue and loss of skeletal muscle in nonobese aging men. J Clin Endocrinol Metab 2008;93:13946. DOI: $10.1210 /$ jc. $2007-1291$

53- Kupelian V, Hayes FJ, Link CL, Rosen R, McKinlay JB. Inverse association of testosterone and the metabolic syndrome in men is consistent across race and ethnic groups. J Clin Endocrinol Metab 2008;93:3403-10. DOI: 10.1210/jc.2008$\underline{0054}$

54- Mårin P, Arver S. Androgens and abdominal obesity. Baillieres Clin Endocrinol Metab 1998;12:441-51. DOI: 10.1016/S0950351X(98)80191-2

55-Nielsen TL, Hagen C, Wraae K, Brixen K, Petersen PH, Haug E, Larsen R, Andersen M. Visceral and subcutaneous adipose tissue assessed by magnetic resonance imaging in relation to circulating androgens, sex hormone-binding globulin, and luteinizing hormone in young men. J Clin Endocrinol Metab 2007;92:2696-705. DOI: 10.1210/jc.2006-1847

56-Plymate SR, Matej LA, Jones RE, Friedl KE. Inhibition of sex hormone-binding globulin production in the human hepatoma (Hep G2) cell line by insulin and prolactin. J Clin Endocrinol Metab 1988;67:460-4. DOI: 10.1210/jcem-67-3-460

57- Kalme T, Koistinen H, Loukovaara M, Koistinen R, Leinonen P. Comparative studies on the regulation of insulin-like growth factor-binding protein-1 (IGFBP-1) and sex hormone-binding globulin (SHBG) production by insulin and insulin-like growth factors in human hepatoma cells. J Steroid Biochem Mol Biol 2003;86:197-200. DOI: 10.1016/S0960-0760(03)00268-1

58- Chubb SA, Hyde Z, Almeida OP, Flicker L, Norman PE, Jamrozik K, Hankey GJ, Yeap $\mathrm{BB}$. Lower sex hormone-binding globulin is more strongly associated with metabolic syndrome than lower total testosterone in older men: the Health in Men Study. Eur J Endocrinol 2008;158:785-92. DOI: 10.1530/EJE-07-0893

59-Pasquali R, Casimirri F, De Iasio R, Mesini P, Boschi S, Chierici R, Flamia R, Biscotti M, Vicennati V. Insulin regulates testosterone and sex hormone-binding globulin concentrations in adult normal weight and obese men. J Clin Endocrinol Metab 1995;80:654-8.

60- Katsuki A, Sumida Y, Murashima S, Fujii M, Ito $\mathrm{K}$, Tsuchihashi $\mathrm{K}$, Murata $\mathrm{K}$, Yano $\mathrm{Y}$, Shima T. Acute and chronic regulation of serum sex hormone-binding globulin levels by plasma insulin concentrations in male noninsulin-dependent diabetes mellitus patients. J Clin Endocrinol Metab 1996;81:2515-9.

61- Pittas AG, Joseph NA, Greenberg AS. Adipocytokines and insulin resistance. J Clin Endocrinol Metab 2004;89:447-52. DOI: 10.1210/jc.2003-031005

62- Hong CY, Park JH, Ahn RS, Im SY, Choi HS, Soh J, Mellon SH, Lee K. Molecular mechanism of suppression of testicular steroidogenesis by proinflammatory cytokine tumor necrosis factor alpha. Mol Cell Biol 2004;24:2593-604.

DOI: 10.1128/MCB.24.7.2593-2604.2004

63- Kalyani RR, Dobs AS. Androgen deficiency, diabetes, and the metabolic syndrome in men. Curr Opin Endocrinol Diabetes Obes 2007; 14:226-34.

DOI: 10.1097/MED.0b013e32814db856

64- Saez JM. Leydig cells: endocrine, paracrine, and autocrine regulation. Endocr Rev 
1994;15:574-626. DOI: 10.1210/edrv-15-5$\underline{574}$

65- Chuzel F, Clark AM, Avallet O, Saez JM. Transcriptional regulation of the lutropin/human choriogonadotropin receptor and three enzymes of steroidogenesis by growth factors in cultured pig Leydig cells. Eur J Biochem 1996;239:8-16. DOI: 10.1111/j.1432-1033.1996.0008u.x

66- Vermeulen A, Kaufman JM, Goemaere S, van Pottelberg I. Estradiol in elderly men. Aging Male 2002;5:98-102. DOI: $\underline{10.1080 / 713604678}$

67- Castro-Fernández C, Olivares A, Söderlund D, López-Alvarenga JC, Zambrano E, Veldhuis JD, Ulloa-Aguirre A, Méndez JP. A preponderance of circulating basic isoforms is associated with decreased plasma half-life and biological to immunological ratio of gonadotropin-releasing hormonereleasable luteinizing hormone in obese men. J Clin Endocrinol Metab 2000;85:4603-10. DOI: $10.1210 /$ jc.85.12.4603

68- Pitteloud N, Mootha VK, Dwyer AA, Hardin $\mathrm{M}$, Lee $\mathrm{H}$, Eriksson KF, Tripathy D, Yialamas M, Groop L, Elahi D, Hayes FJ. Relationship between testosterone levels, insulin sensitivity, and mitochondrial function in men. Diabetes Care 2005;28:1636-42.

DOI: 10.2337/diacare.28.7.1636

69- Chen X, Li X, Huang HY, Li X, Lin JF. (2006) Effects of testosterone on insulin receptor substrate-1 and glucose transporter 4 expression in cells sensitive to insulin. Zhonghua Yi Xue Za Zhi ;86:1474-7.

70- Lin HY, Yu IC, Wang RS, Chen YT, Liu NC, Altuwaijri S, Hsu CL, Ma WL, Jokinen J, Sparks JD, Yeh S, Chang C. Increased hepatic steatosis and insulin resistance in mice lacking hepatic androgen receptor. Hepatology 2008;47:1924-35. DOI: 10.1002/hep.22252

71- Razak F, Anand SS. Impaired mitochondrial activity in the insulin-resistant offspring of patients with type 2 diabetes. Petersen KF, Dufour S, Befroy D, Garcia R, Shulman GI.
N Engl J Med 2004; 350: 664-71. DOI: 10.1056/NEJMoa031314

72- Brehm A, Krssak M, Schmid AI, Nowotny P, Waldhäusl W, Roden M. Increased lipid availability impairs insulin-stimulated ATP synthesis in human skeletal muscle. Diabetes 2006;55:136-40.

DOI:

10.2337/diabetes.55.01.06.db05-1286

73- Yeap BB, Chubb SA, Hyde Z, Jamrozik K, Hankey GJ, Flicker L, Norman PE. Lower serum testosterone is independently associated with insulin resistance in nondiabetic older men: the Health In Men Study. Eur J Endocrinol 2009;161:591-8. DOI: 10.1530/EJE-09-0348

74- Haren MT, Siddiqui AM, Armbrecht HJ, Kevorkian RT, Kim MJ, Haas MJ, Mazza A, Kumar VB, Green M, Banks WA, Morley JE. Testosterone modulates gene expression pathways regulating nutrient accumulation, glucose metabolism and protein turnover in mouse skeletal muscle. Int $\mathrm{J}$ Androl 2011;34:55-68. DOI: 10.1111/j.13652605.2010.01061.x

75- Mootha VK, Lindgren CM, Eriksson KF, Subramanian A, Sihag S, Lehar J, Puigserver P, Carlsson E, Ridderstråle M, Laurila E, Houstis N, Daly MJ, Patterson N, Mesirov JP, Golub TR, Tamayo P, Spiegelman B, Lander ES, Hirschhorn JN, Altshuler D, Groop LC. PGC-1alpha-responsive genes involved in oxidative phosphorylation are coordinately downregulated in human diabetes. Nat Genet 2003;34:267-73. DOI: $10.1038 / \mathrm{ng} 1180$

76-Mårin P, Odén B, Björntorp P. Assimilation and mobilization of triglycerides in subcutaneous abdominal and femoral adipose tissue in vivo in men: effects of androgens. $\mathrm{J}$ Clin Endocrinol Metab 1995;80:239-43. 